\title{
Efficacy of Allium sativum, Curcuma mangga and Acorus calamus Extract Combination on Rat Fertility
}

\author{
Bayyinatul Muchtaromah ${ }^{1, *}$, Roihatul Muti'ah², Desy Rahma Yusmalasari' ${ }^{1}$, Putri Mardyana' , Tanjina Sharmin ${ }^{3}$, \\ Amaq Fadholly ${ }^{4}$
}

Bayyinatul Muchtaromah",*, Roihatul Muti'ah'2, Desy Rahma Yusmalasari', Putri Mardyana', Tanjina Sharmin ${ }^{3}$, Amaq Fadholly ${ }^{4}$

'Department of Biology, Faculty of Science and Technology, Universitas Islam Negeri (UIN) Maulana Malik Ibrahim Malang, Malang 65144, East Java, INDONESIA. ${ }^{2}$ Department of Pharmacy, Faculty of Medicine and Health Sciences, Universitas Islam Negeri (UIN) Maulana Malik Ibrahim Malang, Malang 65144, East Java, INDONESIA.

${ }^{3}$ Department of Chemical Engineering, Faculty of Engineering, Fukuoka University, JAPAN.

${ }^{4}$ Doctoral Student of Veterinary Science Faculty of Veterinary Medicine, Universitas Airlangga, Surabaya, INDONESIA.

\section{Correspondence}

Bayyinatul Muchtaromah

Department of Biology, Faculty of Science and Technology, State Islamic University

of Maulana Malik Ibrahim Malang, Malang

65144, East Java, INDONESIA.

Phone no: +6281231842316;

Fax: +62 $341-558933$

E-mail: bayyinatul@bio.uin-malang.ac.id History

- Submission Date: 03-12-2019;

- Review completed: 18-12-2019;

- Accepted Date: 23-12-2019.

DOI : 10.5530/pj.2020.12.30

Article Available online

http://www.phcogj.com/v12/i1

Copyright

(C) 2020 Phcogj.Com. This is an openaccess article distributed under the terms of the Creative Commons Attribution 4.0 International license.

\begin{abstract}
Objective: to evaluate the efficacy of Allium sativum, Curcuma mangga, and Acorus calamus extract combination on female rat fertility. Methods: Thirty-six female rats were randomized divided into 9 groups $(n=4)$ : $C$ - (no treatment); $C+$ (clomiphene citrate); composition 1 ( $A$. sativum 36\%: C. mangga 36\%: A. calamus 28\%) with 3 doses i.e T1, T2 \& T3 of 50, 75 \& $100 \mathrm{mg} / \mathrm{kg} \mathrm{BW}$; composition 2 (A. sativum 35\%: C. mangga 40\%: A. calamus 25\%) with 3 doses i.e T4, T5 \& T6 of 50, 75 \& 100 mg/kg BW and T7 (Subur Kandungan herb ${ }^{T M}$ ). Treatment was given every day for 15 days. Results: The results revealed that all treatments affected reproductive hormone and uterine histology profile. However, T1 produced the highest estrogen and progesterone levels, and T2 produced the highest endometrial and myometrium thickness, as well as the number of endometrial glands. Furthermore, the hormonal profile in T1 and histological profile of uterus in T2 were not significantly different from those of T7 group. Conclusions: Combined A. sativum, C. mangga, and A. calamus extracts could be used to increase fertility in female rat. The most effective treatment in this study was dose of 50-75 mg/BW in both compositions.
\end{abstract}

Key words: Acorus calamus; Allium sativum; Curcuma mangga; Fertility; Rat.

\section{INTRODUCTION}

Infertility is a reproductive problem experienced by 1 of 6 couples of male and female in the world. ${ }^{1}$ Infertility is defined as the inability of the couples to conceive after one year trying of unprotected sex. ${ }^{2}$ Many factors that can cause infertility and involve male and female. Several factors, including changes in the menstrual cycle and ovulation, hormonal problems, ${ }^{2}$ oxidative stress $^{3}$ and deformity of reproductive organs ${ }^{4}$ were common factors that affect female fertility. However, $25 \%$ of infertility causes are still unknown. ${ }^{2}$ Infertility evaluation sometimes involves many procedures such as physical examination ${ }^{5}$, blood tests (to detect hormonal levels) ${ }^{6}$ and laparoscopy (detection of abnormalities of reproductive organs). ${ }^{2}$

Estrogen and progesterone are essential hormones related to fertility. The primary function of estrogen is coupling behavioral estrus, regulation of menstrual cycle, development of mammary glands, thickening endometrium and the development of female secondary sexual characteristics. ${ }^{7,8}$ Furthermore, the concentration of serum estrogen and progesterone can be used to determine pregnancy and pathological conditions. ${ }^{9}$

There are several options used primarily to address infertility including adopting a healthy lifestyle, using assisted reproductive technology (ART) involves procedure of in vitro fertilization and cryopreservation, using ovulation induction drugs, hormone therapy, and herbs. However, in the recent year's herbs have been used to treat infertility and it is an inclusive practice based on theory, beliefs and experience. ${ }^{10,11}$
Complementary and alternative medicine has become increasingly popular in developed countries. ${ }^{12}$ Even, around $80 \%$ of the total population in developed countries depend on herbal medicines for their primary healthcare because they are cheap, affordable and available in large quantities. ${ }^{13}$ Besides, the use of herbal medicines has been shown to have lower negative effects for the body compared to synthetic drugs. ${ }^{14}$ Therapeutic interventions in modern medicine are based on an understanding of the processes and mechanisms of disease while the use of multicomponent herbal formulas is based on theory and practical experience from thousands of years. ${ }^{15}$

Indonesia is mega biodiversity country that had diverse plant natural resource for herbal medicine. For the people of some area in Indonesia like Java and Madura, traditional medicine better known as herbal medicine (Jamu). One of the herbal medicine that was believed and primarily used to increase fertility by Madurese people of Indonesia is "Jamu Subur Kandungan." It consists of a combination of three materials, namely garlic bulb (Allium sativum), mango ginger rhizome (Curcuma mangga), and sweet flag rhizome (Acorus calamus). Herbal medicines including "Jamu Subur Kandungan" need to be examined scientifically to find out their efficacy with appropriate dosage. Therefore, this study aimed to evaluate the effect of combined Allium sativum, Curcuma mangga, and Acarus calamus extract on female rat fertility at different composition and doses by investigating serum estrogen and progesterone levels and uterine histology profile. 


\section{MATERIALS AND METHODS}

\section{Materials}

Female rat was obtained from the Animal Physiology Laboratory, Faculty of Science and Technology, Universitas Islam Negeri Maulana Malik Ibrahim Malang, Indonesia. Symplisia of A. sativum, C. mangga, and A. calamus were purchased from Balai Materia Medika, Batu Malang, Indonesia. Subur kandungan herb ${ }^{\text {ma }}$ (PJ. Ribkah Maryam Jokotole, Madura), clomiphene citrate (ClomiPHENE, Teva Pharmaceuticals US), hCG (Chorulon, Intervet), PMSG (Folligon, Intervet), estrogen, progesterone, elisa kit (FineTest).

\section{Animal procedure}

Thirty-six fertile female Rattus novergicus (wistar strain) were prepared with the ages around three months old and about 180-230 g body weight. They were placed in the Animal House of Animal Physiology Laboratory Universitas Islam Negeri Maulana Malik Ibrahim Malang maintained temperature $\left(24-26^{\circ} \mathrm{C}\right)$ and humidity $(40-50 \%)$ under light/dark cycle (light on $12 / 12 \mathrm{~h}$ ). They fed with pellet and given water ad libitum. All treatment has been tested through the Health Research Ethics Committee (KEPK) of the Faculty of Medicine and Health Sciences of the Universitas Islam Negeri Maulana Malik Ibrahim Malang (Approval Reference Number: 016/EC/KEPK-FKIK/2018).

\section{Experimental design and research procedure}

The animals were allowed to acclimatize for seven days. Synchronization of the estrus cycle in rats using $10 \mathrm{IU}$ of Pregnant Mare's Serum Gonadotropin (PMSG) by intraperitoneal injection, following by injection of 10 IU Human Chorionic Gonadotropin (hCG) after $48 \mathrm{~h}$. The estrus phase was confirmed by vaginal smears examination and Giemsa staining observed under a microscope with 400x magnification. ${ }^{16}$

This research using completely randomized design with 9 treatments and 4 replications. The groups of treatments were categorized according to the following composition and dosage: Composition 1 consisted of A. sativum $36 \%$ : C. mangga 36\%: A. calamus $28 \%$ and composition 2 consisted of A. sativum $35 \%$ : C. mangga $40 \%$ : A. calamus $25 \%$. The treatment consisting of negative control (C-): no treatment, positive control $(\mathrm{C}+)$ : clomiphene citrate dose of $0.9 \mathrm{mg} / \mathrm{kg} \mathrm{BW}$; $\mathrm{T}$ : composition 1 with dose of $50 \mathrm{mg} / \mathrm{kg} \mathrm{BW}, \mathrm{T} 2$ : composition 1 with dose of $75 \mathrm{mg} / \mathrm{kg}$ BW, T3: composition 1 with dose of $100 \mathrm{mg} / \mathrm{kg} \mathrm{BW,} \mathrm{T4:}$ composition 2 with dose of $50 \mathrm{mg} / \mathrm{kg}$ BW, T5: composition 2 with dose of $75 \mathrm{mg} / \mathrm{kg}$ BW, T6: composition 2 with dose of $100 \mathrm{mg} / \mathrm{kg}$ BW, T7: Subur kandungan herb ${ }^{\text {ta }}$ with dose of $75 \mathrm{mg} / \mathrm{kg}$ BW. All treatments were mixed with $0.5 \mathrm{ml} \mathrm{Na}$ CMC $0.5 \%$ as a solvent.

Extract was prepared following the method of Muchtaromah et al. ${ }^{17}$ and Muchtaromah et al. ${ }^{18}$ The extract was administered according to oral gavage technique. Each rats on treatment T1-T6 received $2 \mathrm{ml}$ extract continuously for 15 days ( 3 times of estrus cycle) after estrus phase while 2 group rats in positive control and T7 were administered according to the prescribed dose which has been explained above. After 15 days, the rats were sacrificed by cervical dislocation, and blood was taken from the aorta for the hormonal assay. The uterus was taken from the abdominal cavity for histology preparations using Hematoxylineosin staining.

\section{Estrogen and progesterone assay}

Measurement of estrogen and progesterone levels was carried out using elisa kit. Blood samples were incubated for $2 \mathrm{~h}$ at room temperature and then centrifuged at $1000 \mathrm{rpm}$ for $15 \mathrm{~min}$. The supernatant obtained was separated from the pellet and put in $2 \mathrm{ml}$ of Eppendorf, then stored in a freezer $-70^{\circ} \mathrm{C}$.

\section{Histological preparation of uterine}

Uterus were fixed in bouin fixative for $24 \mathrm{~h}$. Specimens were dehydrated, embedded in paraffin wax and serially sectioned at 1-6 $\mu \mathrm{m}$ thickness on rotary microtome, followed clearing, hydration, hematoxylin and eosin staining. Slides were observed under light microscope (Olympus CX21, Japan). ${ }^{19}$

\section{Statistical analysis}

The data from this study were analyzed with normality and homogeneity test followed by analysis of variance (ANOVA) with Duncan's Multiple Distance Test. All test used SPSS 15 (SPSS Inc., USA). The differences were considered significant when $\mathrm{p}<0.05$.

\section{RESULTS}

\section{Level of estrogen}

Combination of A. sativum, C. mangga, and A. calamus extract and Subur Kandungan herb increased estrogen levels significantly $(\mathrm{p}<0.05)$ compared to negative control/C- $(525.40 \pm 4.37 \mathrm{ng} / \mathrm{mL})$ (Figure 1). The highest estrogen level was found in T7 group $(971,40 \pm 9.84 \mathrm{ng} / \mathrm{mL})$ but not significantly different $(\mathrm{p}>0.05)$ with T1 $(967.73 \pm 3.51 \mathrm{ng} / \mathrm{mL})$, T3 $(943.07 \pm 4.80 \mathrm{ng} / \mathrm{mL}), \mathrm{T} 4(892.40 \pm 3.22 \mathrm{ng} / \mathrm{mL}), \mathrm{T} 5(884.07 \pm 5.38$ $\mathrm{ng} / \mathrm{mL})$ and T6 $(878.07 \pm 9.80 \mathrm{ng} / \mathrm{mL})$. However, T7 group significantly different from T2 $(811.73 \pm 8.30 \mathrm{ng} / \mathrm{mL})$ and $\mathrm{C}+(794.40 \pm 1.51 \mathrm{ng} / \mathrm{mL})$ and C- (Figure 1).

\section{Levels of progesterone}

The results revealed clomiphene citrate group $(\mathrm{C}+)$ increased significantly $(\mathrm{p}<0.05)$ the levels of progesterone compared to control group/C- $(11.45 \pm 1.76 \mathrm{ng} / \mathrm{mL}$ vs $5.17 \pm 1.74 \mathrm{ng} / \mathrm{mL}$ ) (Figure 2). Interestingly, all treatment with combined A. sativum, C. mangga, and A. calamus extract at all dose treatment increased the progesterone levels T2 $(8.58 \pm 2.64 \mathrm{ng} / \mathrm{mL}), \mathrm{T} 3(10.49 \pm 2.95 \mathrm{ng} / \mathrm{mL}), \mathrm{T} 4(13.46$ $\pm 1.72 \mathrm{ng} / \mathrm{mL})$, T5 $(12.59 \pm 2.42 \mathrm{ng} / \mathrm{mL})$, T6 $(11.75 \pm 3.28 \mathrm{ng} / \mathrm{mL})$. The highest progesterone levels were found in $\mathrm{T} 1(13.78 \pm 2.39 \mathrm{ng} / \mathrm{mL})$ and in Subur Kandungan herb ${ }^{\text {txx }}(8.91 \pm 3.16 \mathrm{ng} / \mathrm{mL})$. In this study, the use of low doses of $50 \mathrm{mg} / \mathrm{kg}$ BW (T1 and T4) were able to increase progesterone levels significantly, while the use of higher doses of 75-100 $\mathrm{mg} / \mathrm{kg}$ BW (T2, T3, T5, T6, T7) tended to reduce progesterone levels (Figure 2). This finding proved that the use of low doses of combined $A$. sativum, C. mangga, and A. calamus extract could induce the optimal production of progesterone levels.

\section{Uterine histological profile}

\section{The endometrium and myometrium thickness}

Figure 3 showed the histological structure of the uterus, which consisted of three layers. Perimetrium or serosa tunica was the outermost layer composed of loose connective tissue. The middle layer was the myometrium, which included thick circular muscles. The inner layer was endometrium which consisted of columnar epithelial layer. Endometrium was in direct contact with uterine lumen where there were glands containing nutrient fluids for the embryo. Thickening of the endometrial and myometrial layers increased the diameter of uterus. Endometrium is an uterine layer that is most responsive to hormonal changes.

The study found that the extract combination at dose of $75 \mathrm{mg} / \mathrm{kg} \mathrm{BW}$ on $\mathrm{T} 2(74.62 \pm 2.41)$, T5 $(74.03 \pm 13.24)$, and $\mathrm{T} 7(84.53 \pm 5.74)$ optimally increased endometrial thickness $(\mathrm{p}<0.05)$ followed by dose of $100 \mathrm{mg} /$ $\mathrm{kg} \mathrm{BW}$ on T6 $(68.40 \pm 2.42)$ and T3 $(60.36 \pm 3.04)$, dose of $50 \mathrm{mg} / \mathrm{kg} \mathrm{BW}$ on T1 $(56.91 \pm 6.71)$ and $\mathrm{T} 4(53.79 \pm 1.94)$. Extract combination also increased significantly myometrial thickness compared to $C-(p<0.05)$. Treatment 7 (31.05 \pm 2.91$)$ exhibited the highest myometrial thickness 
followed by T2 (30.57 \pm 1.92$), \mathrm{T} 1(27.87 \pm 8.65)$, T5 $(23.34 \pm 6.01)$, T3 (20.60 \pm 4.15$), \mathrm{C}+(20.18 \pm 2.01), \mathrm{T} 4(19.44 \pm 1.99), \mathrm{T} 6(18.40 \pm 1.20)$ and C- $(15.61 \pm 2.39)$ (Figure 4$)$.

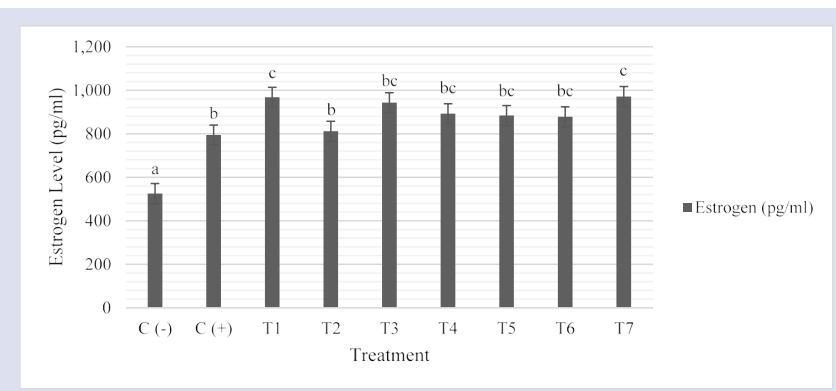

Figure 1: Profile of estrogen levels after treatment.

Note: C- (no treatment), C + (clomiphene citrate $0.9 \mathrm{mg} / \mathrm{Kg} \mathrm{BW}$ ), composition 1:T1 (50 mg/kg BW), T2 (75 mg/kg BW), T3 (100 mg/kg BW) ), composition 2: T4 (50 mg/kg BW), T5 (75 mg/kg BW), T6 (100 mg/kg BW), T7 (Subur kandungan herb ${ }^{\mathrm{TM}}$ of $75 \mathrm{mg} / \mathrm{kg} \mathrm{BW}$ ). The bars represent the mean \pm SD of estrogen level.

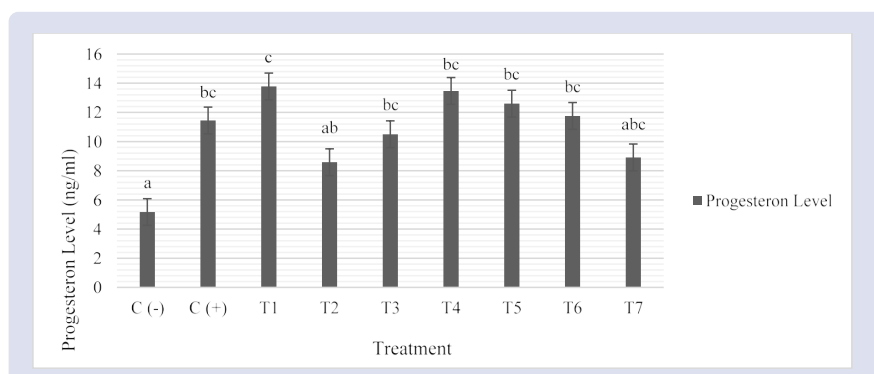

Figure 2: Profile of progesterone level after treatment.

Note: C- (no treatment), C + (clomiphene citrate $0.9 \mathrm{mg} / \mathrm{kg} \mathrm{BW}$ ), composition 1:T1 (50 mg/kg BW), T2 (75 mg/kg BW), T3 (100 mg/kg BW ), composition 2: T4 (50 mg/kg BW), T5 (75 mg/kg BW), T6 (100 mg/kg BW), T7 (Subur kandungan herb ${ }^{\mathrm{Tm}}$ of $75 \mathrm{mg} / \mathrm{kg} \mathrm{BW}$ ). The bars represent the mean \pm SD of progesteron level.
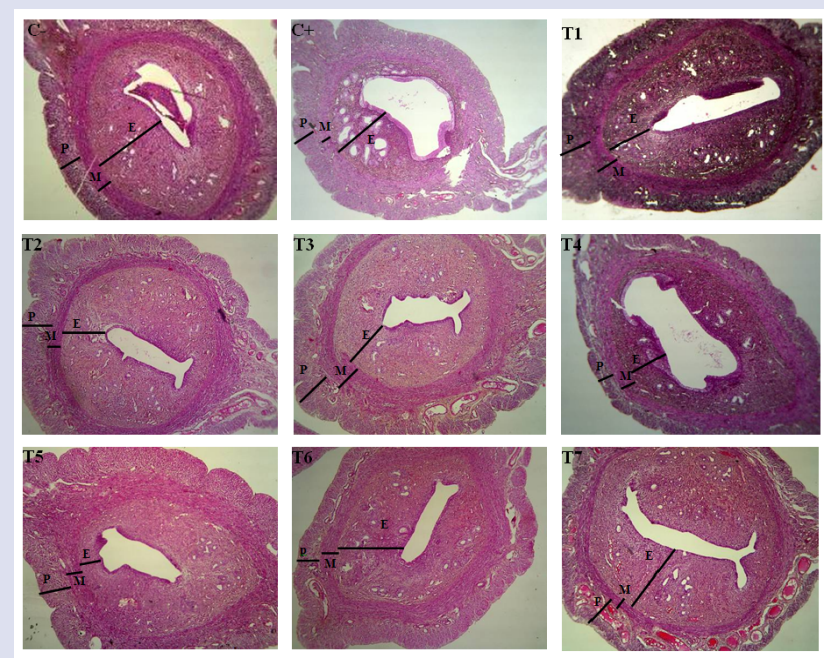

Figure 3: Uterine histological structure after treatment (M: 100x).

E: endometrium, M: myometrium, P: perimetrium C- (no treatment), $\mathrm{C}+$ (clomiphene citrate $0.9 \mathrm{mg} / \mathrm{kg} \mathrm{BW})$, composition $1: \mathrm{T} 1(50 \mathrm{mg} / \mathrm{kg}$ BW), T2 (75 mg / $/ \mathrm{kg}$ BW), T3 (100 mg/kg BW), composition 2: T4 (50 mg/ $\mathrm{kg} \mathrm{BW}$ ), T5 (75 mg/kg BW), T6 (100 mg/kg BW), T7 (Subur kandungan herb $^{\text {TM }}$ of $75 \mathrm{mg} / \mathrm{kg} \mathrm{BW}$ ).
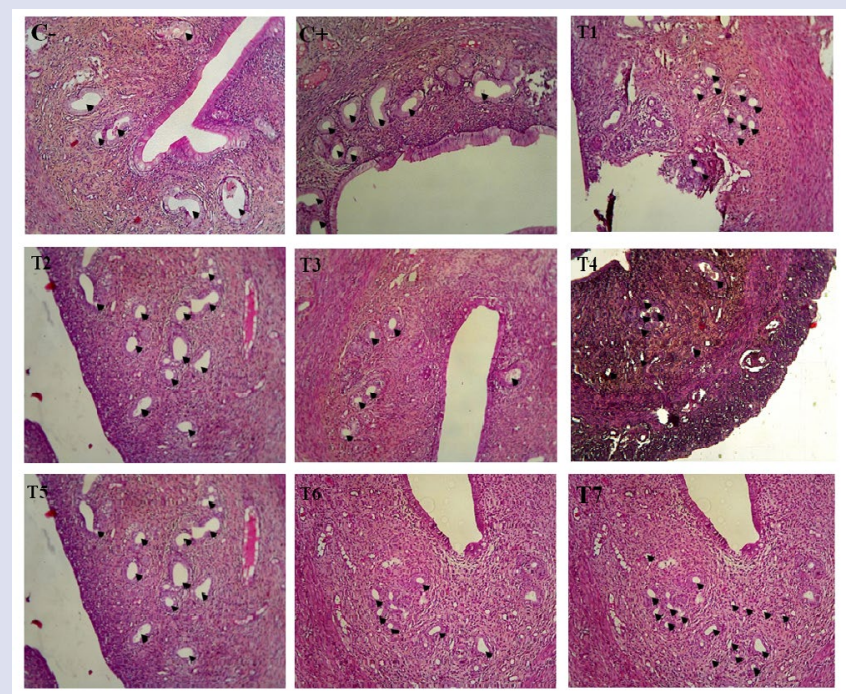

Figure 4: Number of endometrial glands in the cross-section of the uterus. E: Endometrial gland, M: 100 times.

\section{Endometrial glands}

In this study, T7 $(20.66 \pm 2.08)$ showed the highest number of endometrial glands had no significant different with T2 (20.00 \pm $2.64)$ and T5 (19.66 \pm 6.11$)(\mathrm{p}>0.05)$, but different from other groups $(\mathrm{p}<0.05)$. The lowest number of endometrial glands was found at $\mathrm{C}$ $(9.66 \pm 2.51)$ had no different with T4 $(10.33 \pm 3.51)$ and T1 $(12.33 \pm$ 3.05).

\section{DISCUSSION}

\section{Level of estrogen}

Clomiphene citrate was used as a positive control in this study. Clomiphene citrate is a standard drug used to improve female fertility through ovulation induction. However, prolonged use of Clomiphene citrate more than 12 menstrual cycles may increase the risk of ovarian cancer. ${ }^{20}$ Our finding indicated that the combination of $A$. sativum, $C$. mangga, and A. calamus extract with different ratios and doses and Subur kandungan herb ${ }^{\text {Tw }}$ could increase estrogen levels better than clomiphene citrate. Moreover, the combination of A. sativum, C. mangga, and A. calamus extract at the lowest dose of $50 \mathrm{mg} / \mathrm{kg} \mathrm{BW}$ (T1 and T4) tended to increase the estrogen levels, while the highest dose of $100 \mathrm{mg} / \mathrm{kg} \mathrm{BW}$ (T3 and T6) tended to reduce the estrogen levels. This finding was in line with the previous study that combination of $C$. asiatica extract and $P$. indica with doses above $75 \mathrm{mg} / \mathrm{kg}$ BW decreased the estrogen levels. ${ }^{21}$ It is revealed that both combination extracts contain phytoestrogens compound resulted in the similar hormonal response.

We have previously reported that A. sativum, C. mangga, and A. calamus extract contain phytochemical including flavonoid, alkaloid, and triterpenoid compounds..$^{18}$ Similarly, Krizova et al.$^{22}$ reported that some phytoestrogen compounds contained in plants included isoflavones, lignans, coumestans, triterpenic glycosides, and other compounds such as alkaloids, triterpenoids, and chalcone.

Isoflavones belong to the flavonoid group and the largest group in flavonoids. Genistein is one of the derivatives of isoflavone compounds. $\mathrm{Lacy}^{23}$ reported that the structure of genistein and estrogen is almost similar and has an estrogenic effect that can bind to estrogen receptors (ER). According to Primiani et al..$^{24}$ genistein is an isoflavone derivative and is the most estrogenic phytoestrogen while the isoflavone derivative content of combined A. sativum, C. mangga and A. calamus is not elucidated yet and still needs further research. 
The mechanism of action of phytoestrogens is through the direct genomic mechanism, i.e., phytoestrogens directly bind to estrogen receptors (ER) and affect gene transcription, so that it causes estrogen-like effects (estrogenic effect). Phytoestrogens circulate in the bloodstream in a free form and bind to carrier proteins. Phytoestrogens circulate through the membrane by passive diffusion or active transport. ${ }^{25}$

Lecomte et al. ${ }^{26}$ stated that estrogen receptors bind to Estrogen Responsive Element (ERE), which activate some proteins for cell division. When transcribing protein synthesis, estrogen/phytoestrogenreceptor complexes not only bind to ERE but also bind to co-regulator. Furthermore, Fuentes \& Silveyra ${ }^{25}$ revealed that the complexes binding of estrogen affect to transcription and translation as well as the maturation process of folliculogenesis, which triggers ovulation and form a corpus luteum to produce estrogen and progesterone.

\section{Levels of progesterone}

The flavonoids, alkaloids, and triterpenoids content of the extract may act as a phytoestrogen compound and were assumed to cause steroidogenesis (formation of the steroid hormone) in the ovary. As it has been reported phytoestrogens have steroidogenic effects like increasing progesterone level. ${ }^{2}$ Similarly, Shibeshi et al. ${ }^{27}$ showed that genistein in Achyranthes aspera leaf extracts at a dose of 300 and 550 $\mathrm{mg} / \mathrm{kg}$ BW reduced rat progesterone levels. In other hands, Olayaki et al. ${ }^{28}$ reported that genistein in Cajanus cajan extract at dose of 100 and $200 \mathrm{mg} / \mathrm{kg}$ BW increased progesterone receptor expression in the rat's uterus. It showed that the phytoestrogens compound could affect the levels of the progesterone through the negative feedback mechanism of Gonadotropin-Releasing Hormones in the hypothalamus. In this study, combination of A. sativum, C. mangga, and A. calamus extract with different ratios and doses and Subur Kandungan herb ${ }^{\text {tx }}$ could significantly increase both estrogen and progesterone levels.

\section{The endometrium and myometrium thickness}

The appropriate dosage and content of active compounds in combination of A. sativum, C. mangga, and A. calamus extract such as isoflavones, flavonoids, saponins, and alkaloids could affect the endometrium and myometrium thickness (Table 1.). Isoflavones, flavonoids, saponins, and alkaloids stimulate estrogen formation in mammals because their structure is similar to estrogen and bind to estrogen receptors in the uterus, especially the endometrial. The estrogenic effect arises with the bond between phytoestrogens and estrogen receptors, resulting in the activation of estrogen receptors layer. ${ }^{26}$

Table 1: The effect of $A$. sativum, C. mangga, and $A$. calamus extract combination on uterus histology.

\begin{tabular}{|c|c|c|c|}
\hline \multirow[t]{2}{*}{ Treatment } & \multicolumn{3}{|c|}{ Uterus } \\
\hline & $\begin{array}{l}\text { Endometrial } \\
\text { thickness }(\mu \mathrm{m})\end{array}$ & $\begin{array}{c}\text { Myometrial } \\
\text { thickness }(\mu \mathrm{m})\end{array}$ & $\begin{array}{l}\text { Endometrial } \\
\text { glands number }\end{array}$ \\
\hline$C-(N$ & 49. $29 \pm 4.23^{\mathrm{a}}$ & $15.61 \pm 2.39^{\mathrm{a}}$ & $9.66 \pm 2.51^{\mathrm{a}}$ \\
\hline $\mathrm{C}+($ Clomiphen sitrat $)$ & $60.89 \pm 2.35^{\mathrm{bc}}$ & $20.18 \pm 2.01^{\mathrm{a}}$ & $18.66 \pm 3.05^{c}$ \\
\hline T1 $(50 \mathrm{mg} / \mathrm{kg} \mathrm{BW})$ & $56.91 \pm 6.71^{\mathrm{ab}}$ & $27.87 \pm 8.65^{\mathrm{bcd}}$ & $12.33 \pm 3.05^{\mathrm{ab}}$ \\
\hline T2 (75 mg/kg BW) & $74.62 \pm 2.41^{\mathrm{d}}$ & $30.57 \pm 1.92^{\text {cd }}$ & $20.00 \pm 2.64^{c}$ \\
\hline T3 (100 mg/kg BW) & $60.36 \pm 3.04^{\mathrm{bc}}$ & $20.60 \pm 4.15^{\mathrm{ab}}$ & $15.00 \pm 2.64^{\mathrm{abc}}$ \\
\hline $\mathrm{T} 4$ (50) $\mathrm{mg} / \mathrm{kg}$ BW) & $53.79 \pm 1.94^{\mathrm{ab}}$ & $19.44 \pm 1.99^{\mathrm{a}}$ & $10.33 \pm 3.51^{\mathrm{a}}$ \\
\hline T5 (75 mg/kg BW) & $74.03 \pm 13.24^{\mathrm{d}}$ & $23.34 \pm 6.01^{\mathrm{abc}}$ & $19.66 \pm 6.11^{c}$ \\
\hline T6 (100 mg/kg BW) & $68.40 \pm 2.42^{\mathrm{cd}}$ & $18.40 \pm 1.20^{\mathrm{a}}$ & $17.33 \pm 6.11^{\mathrm{bc}}$ \\
\hline T7 (Subur kandungan) & $84.53 \pm 5.74^{\mathrm{d}}$ & $31.05 \pm 2.91^{\mathrm{d}}$ & $20.66 \pm 2.08^{c}$ \\
\hline
\end{tabular}

Note: C- (no treatment), C + (clomiphene citrate $0.9 \mathrm{mg} / \mathrm{kg} \mathrm{BW}$ ), composition 1 T1 (50 mg/kg BW), T2 (75 mg/kg BW), T3 (100 mg/kg BW ), composition 2: T4 (50 mg/kg BW), T5 (75 mg/kg BW), T6 (100 mg/kg BW), T7 (Subur kandungan herb $^{\text {two }}$ of $75 \mathrm{mg} / \mathrm{kg} \mathrm{BW}$ ). The bars represent the mean \pm SD of uterus histology parameter.
Breinholt et al. ${ }^{28}$ reported that isoflavones, genistein, daidzein, equol, and glycitin were estrogenic in mice uterine. $100 \mathrm{mg} / \mathrm{kg}$ body weight of genistein significantly increased uterine weights and the expression of ERa in the uterus. Jefferson et al. ${ }^{21}$ compared the estrogenic potential of several phytoestrogens, including genistein, daidzein, and coumestrol in immature mice using different morphological and biochemical tests on the uterus. Genistein and coumestrol showed estrogenic activity in all experiments, others showed estrogenic activity only a single test.

The mechanism of action of estrogen on endometrial thickness can be explained by estrogen activity in the endometrium. Estrogen activity in cells begins following its binding to receptor in the cytosol. Estrogen and receptor complex diffuse into the cell nucleus and attach to DNA. The binding of the estrogen-receptor complex with DNA induces RNA and protein synthesis and cell division occurs approximately 24-48 hours after the initial stimulus. ${ }^{29}$ The increase of the endometrium and myometrium thickness as well as and endometrial glands number was not only caused by hormonal factors but also by cellular mechanisms of the antioxidant activity of extracts. Herbs containing flavonoids have antioxidant potential to eliminate free radicals and reactive oxygen species. ${ }^{30}$

The phytoestrogens containing in the combination of A. sativum, $C$. mangga and A. calamus in this study might increase the number of cells and stroma (lamina propria) of the endometrium. Endometrial thickness affects a woman's fertility. Thick of endometrium indicates that female is ready to maintaining the growth of fetus. The increase of endometrium width affects the increasing number of glands because under the epithelial layer there are lamina propria which contains many glands that secrete a lot of mucus. Endometrial mucus is known to have a function as nutrition for the embryo. ${ }^{21}$ Increasing of endometrial thickness usually coincided with an increase in the number of glands. ${ }^{31}$

The administration of extracts at dose $50-75 \mathrm{mg} / \mathrm{kg}$ BW (T1, T2, T4, and T5) exhibited an increase in endometrial thickness, myometrium and the number of endometrial glands. The administration of the highest dose of $100 \mathrm{mg} / \mathrm{kg} \mathrm{BW}$ (T3 and T6) tended to decrease endometrial thickness, myometrium and the number of endometrial glands. Estrogenic activity of phytoestrogens is highly dependent on the dose, number, location of estrogen receptors (Rea and $\operatorname{Re} \beta)$, and the concentration of estrogen. ${ }^{26}$ The presence of alkaloid compounds in this study also caused anti-gonadotropic effects in certain doses. Study of Yakubu \& Musa reported that alkaloids in aqueous extract of $S$. alata leaves in dose $250,500,1000 \mathrm{mg} / \mathrm{kgBW}$ exhibite anti-gonadotropic, anti-progesteronic, and feto-maternal toxic activities. Alkaloids show more anti-estrogenic activity (71.43\%) compare to estrogenic activity (28.57\%). It depends on the dose. ${ }^{32}$

\section{Endometrial glands}

The combination extracts increased the number of endometrial glands. Phytoestrogen in combination extracts have high antioxidant property, which have the role of protecting and regenerating cells. ${ }^{34}$ Phytoestrogens also bind to estrogen receptors in the uterus and trigger proliferation and development of the endometrial glands, ${ }^{35}$ which provide nutrients to the embryo. The number of endometrial glands increases during the secretory stage, while the endometrium thickens due to glandular secretion and stromal fluid activity. ${ }^{36}$

Glandular hypertrophy caused by excessive secretion which the gland becomes dilated, the lumen widens and fills with secretions. If the presence of estrogen in the female body is lacking, then phytoestrogens can be a support for endogenous estrogen. The presence of phytoestrogens in small amounts helps to bind to estrogen receptors that are still empty so that there is good support between endogenous estrogens and phytoestrogens in increasing cellular response. ${ }^{35}$ 


\section{CONCLUSION}

The combination of A. sativum, C. mangga, and A. calamus extracts could be used to increase fertility. The combination extract increased estrogen and progesterone levels with an optimal dose of $50 \mathrm{mg} /$ kgBW (T1 \&T4) and also increased the thickness of the endometrium, myometrium, and the number of endometrial glands with a dose of $75 \mathrm{mg} / \mathrm{kgBW}$ (T2 \& T5), but decreased thickness of endometrium, myometrium and the number of glands at a dose of $100 \mathrm{mg} / \mathrm{kg} \mathrm{BW}$ (T3 \& T6).

\section{ACKNOWLEDGEMENT}

The author would like to thank Dr. Bahareh, Didik Wahyudi, Mujahidin Ahmad, Mohammad Basyarudin, Roudlotul Jannah, Sofiyah, Nuril Ainiyah El Syahas for their contribution to the research process and manuscript preparation and Romaidi as Head of Biology Department for supporting the research by laboratory facilities. Furthermore, the author is also very grateful for the research funding of the Faculty of Science and Technology, Universitas Islam Negeri Maulana Malik Ibrahim Malang 2017.

\section{CONFLICTS OF INTEREST}

We declare that we have no conflicts of interest.

\section{CONTRIBUTION OF AUTHORS}

We declare that this work was done by Bayyinatul Muchtaromah, Roihatul Mutiah, Desy Rahma Yusmalasari, Putri Mardyana, Tanjina Sharmin, Amaq Fadholly and all liabilities pertaining to claims relating to the contents of this article will be borne by the authors. Bayyinatul Muchtaromah performed the study design and drafting the manuscript, Roihatul Mutiah performed the data analysis and Desy Rahma Yusmalasari, Putri Mardyana, Tanjina Sharmin, Amaq Fadholly performed the final approval of the manuscript.

\section{REFERENCES}

1. Nath $S$, Deb B. Survey on the effect of plant extract on reproductive parameters of mammals: A review. Int J Pure App Biosci. 2015;3(3):216-23.

2. Kashani $L$, Akhondzadeh S. Female infertility and herbal medicine. J Med Plants. 2017;16:3-7.

3. Zhong R, Zhen, Zhou D, Wei. Oxidative stress and role of natural plant derived antioxidants in animal reproduction. J Integr Agric. 2013;12(10):1826-38.

4. Kachhawa G, Kriplani A. Management of reproductive tract anomalies. J Obstet Gynaecol India. 2017;67(3):162-7.

5. McLaren JF. Infertility evaluation. Obstet Gynecol Clin North Am. 2012;39(4):45363.

6. Murto T Bjuresten K, Landgren BM, Stavreus-Evers A. Predictive value of hormonal parameters for live birth in women with unexplained infertility and male infertility. Reprod Biol Endocrinol. 2013;11(1):1-10.

7. Wallner B, Windhager S, Schaschl H, Nemeth M, Pflüger LS, Fieder M, Seidler H. Sexual Attractiveness: a comparative Approach to Morphological, Behavioral, and Neurophysiological Aspects of Sexual Signaling in Women and Nonhuman Primate Females. Adapt Hum Behav Physiol. 2019;5(2):164-86.

8. Guyton AC, Hall JE. Textbook of medical physiology (13th ed.). Philadelphia: Elsevier: Saunders;2015.

9. Nishanthi M, Vimal M. Experimental and clinical evaluation of contraceptive agents. Int J Pharm Sci Res. 2017;8(10):4046-55.

10. Agha-Hosseini M, Kashani L, Aleyaseen A, Ghoreishi A, Rahmanpour $H$, Zarrinara AR, Akhondzadeh S. Crocus sativus L. (saffron) in the treatment of premenstrual syndrome: A double-blind, randomized, and placebo-controlled trial. Int J Obstet Gynaecol. 2008;115(4):515-9.

11. Akour A, Kasabri V, Afifi FU, Bulatova N. The use of medicinal herbs in gynecological and pregnancy-related disorders by Jordanian women: a review of folkloric practice vs. evidence-based pharmacology. Pharm Biol. 2016;54(9):1901-18.
12. Ekor M. The growing use of herbal medicines: Issues relating to adverse reactions and challenges in monitoring safety. Front Neurol. 2014;4:1-10.

13. Watcho P, Ngadjui E, Alango NEP, Benoît NT, Kamanyi A. Reproductive effects of Ficus asperifolia (Moraceae) in female rats. Afr Health Sci. 2009;9(1):49-53.

14. Sekhri K, Bhanwra S, Nandha R. Herbal products: a survey of students\&\#8217; perception and knowledge about their medicinal use. Int J Basic Clin Pharmacol 2013;2(1):71-9.

15. Pan SY, Litscher G, Gao SH, Zhou SF, Yu ZL, Chen HQ, et al. Historical perspective of traditional indigenous medical practices: The current renaissance and conservation of herbal resources. Evid Based Complement Alternat Med. 2014;2014:525340.

16. Cora MC, Kooistra L, Travlos G. Vaginal cytology of the laboratory rat and mouse: Review and criteria for the staging of the estrous cycle using Stained vaginal smears. Toxicol Pathol. 2015;43(6):776-93.

17. Muchtaromah B, Kiptiyah, Adi TK. Transaminase enzyme and liver histological profile of mice administered extract of pegagan (Centella asiatica (L.) Urban) Media Peternakan. 2011;34(2):88-92.

18. Muchtaromah B, Ahmad M, Sabdoningrum EK, Makrifatul Y, Azzahra VL. (2017) Phytochemicals, Antioxidant and Antifungal Properties of Acorus calamus, Curcuma mangga, and Allium sativum. KnE Life Sci. 2017;3(6):93.

19. El-Zahraa F, Abd-Elhafez EA. A Histological, histochemical and ultrastructural characterization of uterine vessels at early stages of pregnancy. J Histol Histopathol Res. 2018;2(2):41-7.

20. Diergaarde B, Kurta ML. Use of fertility drugs and risk of ovarian cancer. Curr Opin Obstet Gynecol. 2014;26(3):125-9.

21. Muchtaromah B, Mukholifah M, Nasiroh IS, Ahmad M, Romaidi. Antifertility Effect of Centella asiatica (L) Urban and Plucea indica (L) Urban on the Number of Follicles, Antioxidant Activity, and Hormonal Profile of White Rat's Ovaries. Proceedings of the 1st International Conference in One Health (ICOH 2017).; 2017 March 1-2; Paris:AtlantisPress;2017.

22. Krizova L, Dadakova K, Kasparovska J, Kasparovskky T. Isoflavones. Encyclop Diet Suppl. 2019;12:363-72.

23. Lacy A. Studies on coumarins and coumarin-related compounds to determine their therapeutic role in the treatment of cancer. Curr Pharm Des. 2015;10(30):3797-811.

24. Primiani $\mathrm{CN}$, Pujiati $\mathrm{H}$. Estrogenicity of the isoflavone genistein pigeon pie seeds (Cajanus cajan L. Mill sp.) on reproductive organs in rat. IOP Conf. Series: Journal of Physics: Conf. Series. 2018;1025(1):1-9.

25. Fuentes N, Silveyra P.Estrogen receptor signaling mechanisms. Adv Protein Chem Str. 2019;116:135-70.

26. Lecomte S, Demay F, Ferrière F, Pakdel F. Phytochemicals targeting estrogen receptors: Beneficial rather than adverse effects. Int J Mol Sci. 2017;18(7):1-19.

27. Shibeshi W, Makonnen E, Zerihun L, Debella A. Effect of Achyranthes aspera $L$. on fetal abortion, uterine and pituitary weights, serum lipids, and hormones. Afr Health Sci. 2006;6(2):108-12.

28. Olayaki LA, Olatunji-bello I, Soladoye AO. Effects of aqueous leaf extract of Cajanus cajan on litter size and serum progesterone in pregnant rats. J Pharmacognosy Phytother. 2009;1(2):021-4.

29. Breinholt V, Hossaini A, Svendsen GW, Brouwer C, Nielsen E. Estrogenic activity of flavonoids in mice. The importance of estrogen receptor distribution, metabolism and bioavailability. Food Chem. Toxicol. 2000;38:555-64.

30. Grubber CJ, Tschugguel W, Schneeberger C, Huber JC. Mechanisms of Disease. N Engl J Med Rev. 2002;346(5):340-52.

31. Kasote DM, Katyare SS, Hegde MV, Bae H. Significance of antioxidant potential of plants and its relevance to therapeutic applications. Int J Biol Sci. 2015;11(8):982-91.

32. Nephew KP, Long X, Osborne E, Burke KA, Ahluwalia A, Bigsby RM. Effect of Estradiol on Estrogen Receptor Expression in Rat Uterine Cell Types 1. Biol Reprod. 2000;62:168-77.

33. Yakubu MT, Musa IF. Effects of post-coital administration of alkaloids from Senna alata (Linn. Roxb) leaves on some fetal and maternal outcomes of pregnant rats. J Reproduction Infertil. 2012;13(4):211-7.

34. Jefferson WN, Padilla-Banks E, Clark G, Newbold RR. Assessing estrogenic activity of phytochemicals using transcriptional activation and immature mouse uterotrophic responses. J Chromatogr B Analyt Technol Biomed Life Sci. 2002;777(1-2):179-89.

35. Wocławek-Potocka I, Mannelli C, Boruszewska D, Kowalczyk-Zieba I, Waśniewski T, Skarzyński DJ. Diverse effects of phytoestrogens on the reproductive performance: Cow as a model. Int J Endocrinol. 2013;2013:1-15

36. Gellersen B, Brosens JJ. Cyclic decidualization of the human endometrium in reproductive health and failure. Endocr Rev. 2014;35(6):851-905 


\section{GRAPHICAL ABSTRACT}

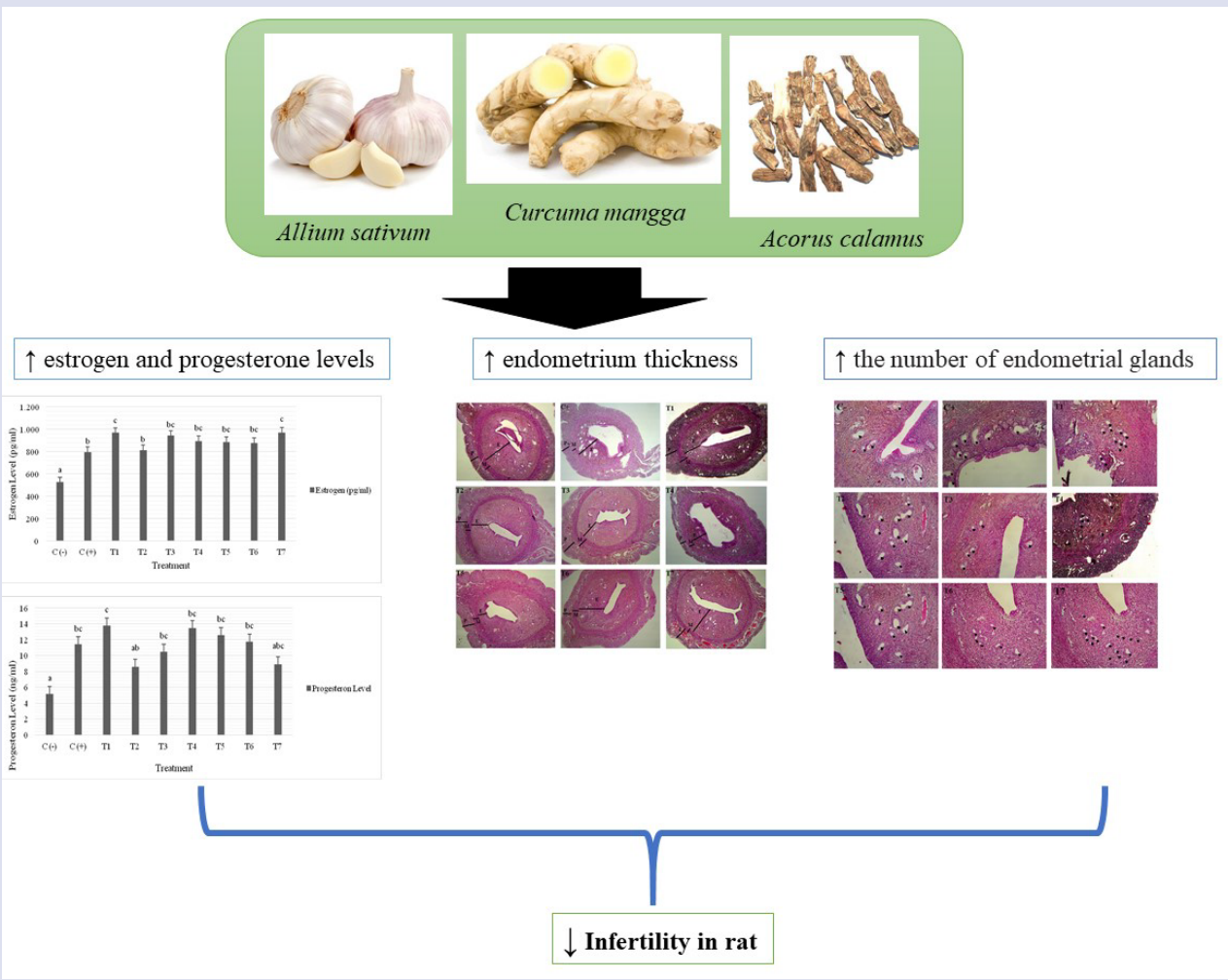

\section{ABOUT AUTHORS}

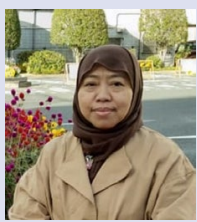

Bayyinatul Muchtaromah received her doctoral degree at Brawijaya University, Indonesia (2007). She is currently a lecturer at Universitas Islam Negeri (UIN) Maulana Malik Ibrahim Malang, Indonesia. Her research interest includes animal physiology and reproduction.

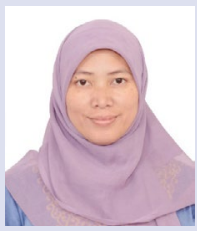

Roihatul Muti'ah received her doctoral degree at Airlangga University (2017). She is a lecturer at Universitas Islam Negeri (UIN) Maulana Malik Ibrahim Malang, Indonesia. Her research interest includes phytochemistry, natural product, biological activity, and pharmacology.

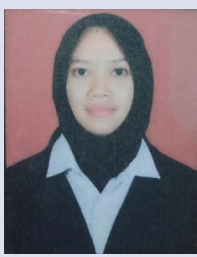

Desy Rahma Yusmalasari received her bachelor degree at Universitas Islam Negeri (UIN) Maulana Malik Ibrahim Malang, Indonesia. Her current research is about animal reproduction.

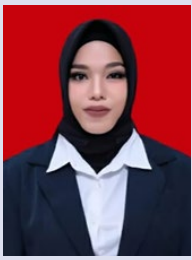

Putri Mardyana received her bachelor degree at Universitas Islam Negeri (UIN) Maulana Malik Ibrahim Malang, Indonesia. Her current research is about animal reproduction. 
Tanjina Sharmin received her doctoral degree at Fukuoka University, Japan (2013). She is a researcher at Department of Chemical Engineering, Faculty of Engineering, Fukuoka University, Japan. Her expertise includes immunology of infectious disease and supercritical fluid extraction.

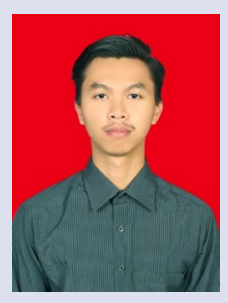

Amaq Fadholly is a PhD student in Veterinary Science of Universitas Airlangga, Indonesia. He is currently as a teaching assistant on Department of Pharmacology, Faculty of Veterinary Medicine, Universitas Airlangga. His research interest are pharmacology, biomedical science and molecular biology.

Cite this article: Muchtaromah B, Muti'ah R, Yusmalasari DR, Mardyana P, Sharmin T, Fadholly A. Efficacy of Allium sativum, Curcuma mangga and Acorus calamus Extract Combination on Rat Fertility. Pharmacog J. 2020;12(1):197-203. 